\title{
The Analysis of SWOT Management in Pra Pelatnas Training Center of Persatuan Atletik Seluruh Indonesia (PASI), East Java
}

\author{
Selvy Cahya Wulandari ${ }^{1}$, Amrozi Khamidi ${ }^{2}$, Gigih Siantoro ${ }^{3}$ \\ 1,2,3 Postgraduate Program in Sport Education, Universitas Negeri Surabaya, Indonesia \\ inuelek@gmail.com
}

\begin{abstract}
In the science of sports management, it is explained that the optimal performance of an athlete is inseparable from the application of management functions in the sports organization. The participates in. PASI Pengprov East Java as the organizer of the Pre Pelatnas Training Center should have good management so that all activities run smoothly and succeed in achieving their goals to identify the readiness level of each management function. Training Center Pra Pelatnas PASI East Java Pengprov in an effort to achieve its goals, it is necessary to do an analysis. A fairly good method for analyzing management functions is SWOT analysis. This study is focused on analyzing and identifying the strengths, weaknesses, opportunities and threats in each management function, namely, Planning (organizing), implementation (actuating), evaluation (controlling). The implementation of Training Center Pra Pelatnas PASI East Java Pengprov. This type of research is a qualitative research with a descriptive method approach. Sources of research data come from observations, interviews with administrators, coaches and athletes and documents. The data obtained will be analyzed using triangulation techniques, namely data validation by checking the facts obtained from different data sources. The results of the SWOT analysis on management generally conclude that the management process Training Center It can be said that the Pre Pelatnas for the Indonesian Athletics Association (PASI) East Java Provincial Government has been carried out quite effectively in all management functions, namely Planning, Organizing, Actuating, and Controlling and has achieved good and appropriate results. However, improvements and proper strategies are still needed to minimize existing weaknesses and overcome threats.
\end{abstract}

Keywords

SWOT analysis; manajement; training ccenter pra pelatnas; and PASI Province

Committee

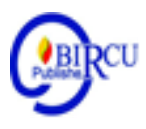

\section{Introduction}

Athletics is the barn that generates the most medals in sports events because it has many competitions. Athletic competitions have always been the main event in organizing sports parties from the regional level to PON, Asian Games, Sea Games, even the Olympics. In Indonesia it is not an easy thing to find seeds for athletic athletes because many are more interested in pursuing popular sports, such as soccer, volleyball, basketball and others.

PASI province committee of east java is an area that sends many athletes to participate in athletic events at the national level. In the XIX PON which was held on 17-29 September 2016 in West Java, the East Java athletic team won a total of 16 medals consisting of 4 gold medals, 9 silver medals and 3 bronze medals. And at the Athletic National Championship at 
the Rawamangun Athletic Stadium, Jakarta, which started from 6 - 9 December 2017, East Java was victorious and won the overall champion with a collection of eight gold medals, eight silver and six bronze medals. (Mercy Raya, 2017)

However, there are obstacles that must be faced by PASI province committee of east java in its efforts to improve the achievements of athletic sports in East Java. One of the problems that occur is the slow regeneration of athletes. The slow pace of emerging potential athletes has hampered the regeneration of athletes who should have been running well. Many senior athletes who have retired still do not have replacements.

In mid-2017, PASI province committee of east java established a Pra Pelatnas Training Center which was centered in Lidah Wetan Village, Lakarsantri District, and Surabaya Municipality. This Training Center was formed with the aim of preparing talented young athletes who had been previously selected to replace senior athletes to achieve their highest achievement. This is in accordance with the principle of long-term athlete development as indicated by Article 5 paragraphs 1 and 2 of the Presidential Decree Number 95 of 2017 which reads "The development of talent for Achieving Athletes is carried out by the Main Sports Branch Organization and the NPC (National Paralimpic Committee of Indonesia).

"Training" is an attempt to systematically improve the performance of athletes. In order for the training process to run well, athletes are gathered at a place which is usually called the mess or boarding house and given a training program for a certain period of time before facing competitions. The explanation above is known as the Traning Center. The training concentration is carried out for a certain period of time, even years. The whole activity.

\section{Review of Literatures}

PASI province committee of east java Pra Pelatnas Training Center is inhabited by potential athletic athletes aged 16-22 years. The Training Center program is based on sports science which covers all the things that athletes need to achieve and improve their achievements. There are three aspects, namely physical, nutritional health and psychology in sports science that underlie the management system and athlete development.

Training center as a sport activity that involves many components must have good management. Management is one of the important elements in an activity or organization because there is a division of labor, duties and responsibilities. In general, management is a skill or expertise to get success in achieving goals by doing activities with other people. (Harsuki, 2012).

In sports management, it is explained that the highest achievement of an athlete cannot be separated from the effectiveness of management functions that exist in the sports organization that he participates in. According to Terry (2016), management functions are typical activities carried out in a management which consists of various stages and are interrelated with one another in an effort to achieve the goals of an activity or organization. These management functions consist of planning (organizing), implementation (actuating), and evaluation (controlling).

PASI province committee of east java as the organizer of the Pre Pelatnas Training Center should have good management in order to achieve the specified targets. An evaluation is needed to assess whether the management in the Pre Pelatnas Training Center activities has been going well or vice versa so that the management can determine better steps or strategies for the future. 
To explore management functions in an activity or organization, the use of a SWOT analysis is an effective way. SWOT analysis is the most basic method used to evaluate strengths, weaknesses, opportunities, and threats in an activity or organization. SWOT analysis takes the form of a descriptive situation and condition analysis (giving an overview). This analysis is based on a point of view that can increase strengths and opportunities, but can minimize external weaknesses and threats. (Rahmat, 2014). If the SWOT analysis is applied correctly, it will help us to identify parts of the activity or organization that have been invisible and forgotten so far. This analysis will be applied to each management function so that the results are more detailed.

Terry, in Sulaiman (2020) management is a process or framework that involves the guidance or direction of a group of people towards organizational goals or real intentions. Of the several opinions all focus on coordinating the activities of existing resources in an organization to achieve goals. Terry, (2001) suggested that management has 4 functions, namely: (1) planning, (2) organizing, (3) moving, and (4) supervising or controlling), based on the theory, the researcher begins this research by looking from management functions are carried out properly. The existence of managers in an organization is very necessary because the organizationas a tool used to achieve organizational goals (Musdiani, 2019).

According to David (2004) the SWOT analysis provides results in the form of recommendations, suggestions and directions to maintain existing strengths and increase the benefits of opportunities that arise while reducing deficiencies and also avoiding threats to an activity or organization. The results of this analysis can be used as a reference / reference for managing strategies for developing athletic sports performance in East Java.

\section{Research Method}

The focus of this research is how to analyze the SWOT for each management function, namely planning, organizing, actuating and controlling the Training Center for the Pra Pelatnas PASI province committee of east java. This type of research is qualitative research through a descriptive method approach. Qualitative research is intended to understand phenomena descriptively in the form of words experienced by research subjects such as behavior, perception, motivation, action, and others as a whole. The data obtained and collected are in the form of words and pictures, and do not make numerical calculations on the data obtained.

Sources of data come from observations in the field, the results of interviews with administrators, trainers and athletes and documents. The data collection technique uses overt observation and covert observation, interviews, and documents.

The data obtained will be analyzed using triangulation, namely data validation by checking the facts obtained from different data sources or other data sources. The analysis process is carried out by studying and reviewing data / information obtained from various sources, namely interviews, observations, documentation and so on. 


\section{Discussion}

\subsection{SWOT Analysis on the Planning Function of the Training Center Pra Pelatnas PASI Province Committee of East Java}

Planning is a function that includes the process of determining the vision and mission, setting goals, setting programs, arranging management, division of tasks, funding, recruiting coaches, recruiting athletes and assigning trainers or athletes in the Training Center Pra Pelatnas PASI province committee of east java. An analysis of each SWOT component is needed to assess the strengths and weaknesses of existing resources and see the opportunities and challenges / threats that will be faced in planning (Jogiyanto, 2005). In this case the study will analyze and discuss using a SWOT approach to the planning (planning) of the Training Center Pra Pelatnas PASI province committee of east java. And the results are as follows:

\section{a. Strength}

1. The goal has been set quite well, namely to attract young athletes to carry out longterm training camps so that in the future these athletes can be prepared for junior international championships or be able to replace some senior athletes who when participating in international championships experience obstacles to the age limit for participating in competitions.

2. Recruitment of coaches and athletes has a clear flow or mechanism.

3. There is a physical condition test, anthropometric test and psychological test at the athlete selection stage to get athletes who are truly superior.

4. The organizational structure has been formed and the job descriptions of each structure have been divided clearly and specifically so that they do not overlap. With a clear division of tasks between holders of structures will make each personnel focus with their respective field expertise.

\section{b. Weakness}

1. There are no clear indicators or standards for the talent scouting team to recruit athletet

2. Funding that is independent and comes from one source is prone to unilaterally terminated, considering that this coaching funding is very dependent on the policies of donors or sponsors, which in funding a sport coaching require large funds every year.

3. Recruitment of trainers of identical trainers must have sufficient licenses to train in this program, but some trainers have not received the appropriate license. Only with training experience in the field and recommendations from several PASI pemcab and pengcab can they be considered to be able to train in this Training Center Pra Pelatnas PASI province committee of east java

4. The absence of job specifications for the arrangement of management personnel for the Training Center Pra Pelatnas PASI province committee of east java which is quite clear considering that this program was designed for the first time in East Java 


\section{c. Opportunity}

1. The East Java Pengprov Pre Pelatnas Training Center Program can be an example for other sports in terms of training athletes for pre-adolescents, adolescents and juniors.

2. This plan was made not only for the national level but also to support the needs of PASI to recruit new athletes who are destined to face international level championships.

\section{d. Threat}

There are several problems experienced by the athlete recruitment team, namely having a conflict of interest situation when carrying out their duties to select athletes and coaches. The lack of objectivity of the talent scout or the recruitment team to carry out the selection process due to the pressure of the interests of various parties.

\subsection{SWOT Analysis on the Organizing Function of the Training Center Pra Pelatnas PASI Province Committee of East Java}

Organizing is the process of preparing an organizational structure in accordance with the targets and resources owned. In this function, actions are needed to group all the appropriate capabilities into one place and take advantage of these capabilities to be useful for this organization (Robbins and Coulter: 2007). Organizing does not only regulate the grouping of human resources, but also together with other resources so that it can run more effectively. Edwin B. Flippo in Tanjung (2020), stated that personnel management is the process of planning, organizing, directing and controlling the procurement of labor, development, compensation, integration, maintenance and termination of employment with a view to achieving the goals or objectives of individuals, organizations, and the community their work or work relationship.

\section{a. Strength}

1. Trainers who have joined and excel in the Training Center Pra Pelatnas PASI province committee of east java who do not yet have a trainer certificate / license will be sent by PASI Pengprov East Java to take coaching courses to get a trainer license based on the number trained.

2. The trainer is given the authority to compile his own training program by involving and discussing it with experts in structural.

3. The division of hours of exercise and rest which is sufficiently clear and does not interfere with other activities outside of rest and practice hours.

\section{b. Weakness}

1. There are some trainers who do not have a license to train

2. Human Resources from the board who do not know too much about athletic development for young age athletes.

3. The relegation promotion system is prone to changing coaches which can have an impact on athletes to adjust to the new coach.

\section{c. Opportunity}

The period of service which is used as a prerequisite for occupying the organizational structure in this guidance will lead to structural changes in management within a certain period of time. 


\section{d. Threat}

Without good quality Human Resources, no matter how good the organizational system is, it will not work as it should.

\subsection{SWOT Analysis on the Actuating Function of the Training Center Pra Pelatnas PASI Province Committee of East Java}

Actuating is an effort to mobilize all members of the organization to achieve goals according to planning. The actuating function places more emphasis on activities that are directly related to personnel in the Training Center Pra Pelatnas PASI province committee of east java. Good planning and organization will be of little meaning if it is not followed by the activities of all potential human and non-human resources in the implementation of their duties.

Each resource must work in accordance with their respective duties, functions, roles, expertise and competencies to carry out the activities that have been programmed (Handayani, 2014).

\section{a. Strength}

1. The implementation of an exercise program is supported by comprehensive science (Sport Science)

2. Athletes can participate in the International Junior Championship

3. Study athletes who are not ruled out

4. Daily attendance which is conducted to measure the level of discipline and to maintain consistency in the attendance of athletes and coaches in the Training Center Pra Pelatnas PASI Province Committee of East Java

5. Daily food menus are prepared by nutritionists who are experienced in handling menus for athletes

6. The welfare of athletes and coaches is guaranteed, including giving bonuses for athletes, coaches and parents or guardians of athletes who excel

\section{b. Weakness}

1. Study of athletes is compromised by the existence of a strict training schedule.

2. Schedule for international championships that coincide with school exams.

3. There is no doctor or health worker who is available 24 hours a day at the hostel.

4. Some of the facilities and infrastructure for training were damaged

5. The training program is structured to change in view of the promotion of coach relegation which can interfere with athlete's performance.

\section{c. Opportunity}

1. Athletes whose name will be promoted to the next level will motivate other athletes.

2. Increase awareness of athletes regarding nutritional intake that needs to be consumed.

3. Motivating athletes in training in order to compete at the international level.

\section{d. Threat}

1. Changes in training programs due to promotion and relegation of coaches.

2. Equipment at certain numbers is inadequate.

3. Constrained when entering the rainy season which results in disruption of the training schedule in the afternoon session 


\subsection{SWOT Analysis on the Controlling Function of the Training Center Pra Pelatnas PASI Province Committee of East Java}

According to Terry (2016), supervision is a process of determining standards (something that needs to be achieved), implementation (what is being done), assessing the implementation process and making improvements, so that implementation is in accordance with predetermined plans and standards.

Routine supervision is carried out periodically by the director of the Training Center Pra Pelatnas PASI province committee of east java by monitoring directly or indirectly the performance of functional personnel in structural or coaches and athletes. And also the holding of regular meetings from PASI committee of east java regarding developments in the field technically or non-technically.

\section{a. Strength}

1. Evaluation of the results of training is carried out periodically to see if the implementation of the exercises is in accordance with the program the trainer has made.

2. Conducted evaluation before and after participating in the competition

3. The holding of regular physical tests as a basis for preparing an exercise program

4. There is an evaluation for the management in the structural.

b. Weakness

1. Standards or norms for the level of the athlete's physical condition are not clearly described

2. Lack of regular reports on athlete's health.

3. There is no target per race number in one year following the championship.

\section{c. Opportunity}

The coach's report regarding the implementation of training and athlete's achievement in participating in the championship and evaluation from the management is a control if something goes wrong with the target. This is related to the promotion of relegation which will give rise to new names, both coaches and more potential athletes.

\section{d. Threat}

1. Some administrators have problems in this coaching due to activities outside this program

2. Athletes who experience injuries will leave training a lot because they have to carry out injury rehabilitation.

3. The target number of coaches and athletes that have been determined has not been achieved.

\section{Conclusion}

\subsection{Conclusion}

Based on the results of research and discussion, it can be concluded as follows:

1. Planning in the Training Center Pra Pelatnas PASI province committee of east java has been done well. Based on the indicators put forward by the resource persons and documents that this program has clear achievement sports coaching objectives, the 
recruitment mechanism for athletes and coaches is clear and in accordance with the required criteria, an organizational structure has been formed and is able to utilize the human resources in it. every field. Funding, standards or norms for the recruitment of athletes and the specification of the duties of the management structure are deficiencies that must be addressed immediately so that the goal of this program, namely achievement, can be achieved.

2. Organizing has been carried out and executed well, there is already a clear division of tasks or work and a good organizational structural component. This can be seen from the organizational structure which already has their respective main tasks and functions and clear relationships between members in each field. Trainers are given the opportunity to develop themselves both inside and outside the program.

3. The process of implementing Training Center Pra Pelatnas PASI province committee of east java has been carried out well and effectively. Communication is well established between administrators, coaches and athletes both formally and informally. Discipline, nutrition / nutrition, education and athlete welfare have been met, but there are several obstacles in the implementation of this program, namely the lack of fulfillment of standards for some training facilities and infrastructure.

4. In supervision, the implementation of Training Center Pra Pelatnas PASI province committee of east java can be said to be running well and effectively. This can be seen from the findings of researchers when looking at the evaluation process and evaluation stages which are carried out periodically, namely by setting standards according to the initial planning. However, this standard has not been stated in the official document as a target reference in any evaluation in the implementation of the exercise. Measuring the condition of athletes by means of physical tests and holding regular meetings and coordination are used as basic materials or references when doing promotions and relegation.

Based on the findings of the researchers above, it is generally concluded that the management process of the Training Center Pra Pelatnas PASI province committee of east java can be said to have been carried out quite effectively in all management functions, namely Planning, Organizing, Actuating, Controlling and has achieved good and appropriate results.

\subsection{Suggestion}

Based on the conclusions of the research results, several suggestions related to management functions in the Training Center Pra Pelatnas PASI province committee of east java can be put forward as follows

a. On the Planning Function

1. It is necessary to develop clear instruments or indicators on each criterion for each sporting number for the athlete recruitment process. This is to avoid the subjectivity of the talent scouting team and to get the best athletes.

2. The PASI province committee of east java makes job specifications to fill the right personnel in the organizational structure of the Training Center Pra Pelatnas PASI province committee of east java program. This is in accordance with the opinion of Stone (2005) that job specifications are needed to fill the right personnel in the organizational structure. Job specifications represent the minimum requirements for personnel to be recruited in order to carry out a task / job properly and competently.

3. Considering that this program is a long-term coaching program that requires large funds, PASI province committee of east java should seek sponsors and donors from companies or individuals who are adequate and concerned about athletic sports, for 
example BUMN so that the Training Center Pra Pelatnas PASI province committee of east java program can continue to run.

\section{b. On the Organizing Function}

1. The importance of human resources in the organizational structure of Training Center Pra Pelatnas PASI province committee of east java to participate in trainings in an effort to develop quality and increase the productivity of their performance.

\section{c. On the Actuating Function}

1. It needs to be considered fully home schooling as a substitute for formal education so that athletes are more focused on training and participating in competitions

2. Management of the Training Center Pra Pelatnas PASI province committee of east java immediately looks for the right solution for the availability of facilities and infrastructure that meet standards

\section{d. On the Controlling Function}

1. Considering the importance of the physical condition of an athlete as the basis for the preparation of the next training program, as well as evaluating the readiness of the athlete's physical condition in participating in the championship, the administrators of Training Center Pra Pelatnas PASI province committee of east java need to make standardized tests and measurements of standard physical conditions for each athletic number.

2. It is necessary to set written targets for the championships to be participated in for one year so that the goal can be more focused.

\section{References}

David, F.R (2004). Manajemen Strategis : Konsep. Edisi ketujuh. : Jakarta : PT. Prenhallindo

Handoko, T. ( 2001). Manajemen Edisi 2. Yogyakarta : BPFE

Harsuki. (2012). Pengantar Manajemen Olahraga. Jakarta : PT. Raja Grafindo Persada

Jogiyanto, H.M (2005). Analisa dan Desain Sistem Informasi. Pendekatan Terstruktur Teori dan Aplikasi Bisnis. Yogyakarta : Andi

Moleong, L., (2011). Metode Penelitian Kualitatif. Bandung : PT. Remaja Rosdakarya

Musdiani, Mardhatillah, and Kausar. (2019). Analysis the Role of Headmaster in Applying Quality of Education in Primary School Districts, Aceh Barat. Budapest International Research and Critics in Linguistics and Education (BirLE) Journal Vol 2 (3): 27-35.

Osita, C., Onyebuchi, R., \& Justina, N. (2014). Organization's Stability And Productivity: The Role Of SWOT Analysis An Acronym For Strength, Weakness, Opportunities And Threat. International Journal of Innovative and Applied Research (2014), Volume 2, Issue (9):23-32

Rahmat, Z. (2014). Analisis Manajemen Pembinaan Atlet Atletik PPLP Aceh. Jurnal Ilmiah Pendidikan Jasmani Kesehatan dan Rekreasi Volume I Nomor 1. Januari Juni 2014

Rangkuti, F. (2017). Analisis SWOT Teknik Membedah Kasus Bisnis. Jakarta. : PT. Gramedia Pustaka Utama. 
Raya, M. (2017, Desember 10). Jawa Timur Juara Umum Kejurnas Atletik 2017. https://sport.detik.com/sport-lain

Robbins, Stephen P. dan Coulter, Mary (2010). Manajemen edisi Kesepuluh. Jakarta : Penerbit Erlangga

Stone, Raymond J. (2005). Human Resources Manajement, Fifth Edition. Australia, Willey.

(2017). Peningkatan Prestasi Olahraga. Peraturan Presiden Republik Indonesia No 95 Tahun 2017

Sulaiman, Khamidi, A., and Mintarto, E. (2020). The Evaluation of Athletic Extracurricular Management of Dr. Soetomo and Jalan Jawa Junior High School in Surabaya. Budapest International Research and Critics in Linguistics and Education (BirLE) Journal Volume 3 (1): 11-19.

Tanjung, B.N. (2020). Human Resources (HR) In Education Management. Budapest International Research and Critics in Linguistics and Education (BirLE) Journal Vol 3 (2): 1240-1249. 